\title{
DIVERSIFICATION OF PROPERTY MANAGERS' FEES AND THEIR DETERMINANTS - THE CASE OF POLAND
}

\author{
Joanna Wegrzyn \\ Department of Real Estate Economics and Investment Process \\ Cracow University of Economics \\ email:wegrzynj@uek.krakow.pl \\ Katarzyna Najbar \\ Department of Real Estate Economics and Investment Process \\ Cracow University of Economics \\ email:najbark@uek.krakow.pl
}

\begin{abstract}
The article aimed to determine (1) what factors affect the rates of property management fees (2) and to examine whether the rates declared by managers can be an essential factor in the segmentation of the property management services market. The research has been divided into two stages. First, the review of the literature allowed us to elaborate a list of factors affecting the rates for property management fees. Then, the research was based on the analysis of the results of questionnaires obtained from property managers. We gathered a sample of 368 responses, which enabled us to use the analysis of variances. This statistical method was utilized to answer the second research question.
\end{abstract}

Key words: property management,service property management fees, payment mechanism.

JEL Classification: $R 30, R 33, O 18$.

Citation: Węgrzyn, J., Najbar, K. (2020). Diversification of property managers' fees and their determinants - the case of Poland, Real Estate Management and Valuation, 28(1), 41-50.

DOI: $10.2478 /$ remav-2020-0004

\section{Introduction}

Traditionally we perceive a property manager as someone who collects rents, shows space, signs leases, and, in general, maintains order on the managed property. However, the demand for property management service is changing, which can be contributed to a wide range of reasons. Among them is the growing number of newly built facilities or growing competition on the market. A need to revise the role of a property manager is also induced by a shift in attitude towards the value of the property itself. Vargo and Lusch state that, nowadays, we tend to accept that value that extends beyond valuein-exchange embedded in products or services delivered to a customer to include value-in-use, defined as a customer's outcome, purpose, or objective that is achieved through a service (Vargo \& Lusch, 2008). In other words, property managers are starting to play an essential role in property value co-creation (Read \& Carswell, 2018). They take responsibility for facilitating the clarification of the roles and obligations of all parties engaged in the process of property management, facilitating marketing efforts, and speeding up service processes by reducing the number of transactions or interactions needed (Nätti et al., 2014). Finally, property managers act as conciliators when the need to mitigate conflicts arises. This broader approach to property management reaches far beyond shortterm tasks and assumes a proactive role of the manager (Muczyński, 2015). 


\section{S sciendo}

That is why property managers often have difficulty with establishing the level of remuneration for property management services and other fees when submitting a management proposal. In the majority of management proposals, the company's primary objective is to generate a profit; however, there are situations when other reasons take precedence over generating a profit. Such situations usually occur when income or additional benefits can be generated from other activities included along with managing the property (Muhlebach \& Alexander, 2007).

In the article, we investigated what factors determine fees in service property management. Following Żelazowski (2011), we started with the assumption that two types of factors that exert an impact on the rate of property management fees can be distinguished. Most of them can be directly attributed to a particular function of property management, and, in general, these factors constitute the core of property management fees. However, we claim that, among a wide range of factors, we can indicate those that differentiate property management fees.

Thus, the aim of the research was twofold. First, based on a comprehensive literature review we focused on the identification and categorization of the determinants of service property management fees. We then analyzed data obtained from a survey conducted among property managers to verify what factors differentiate property management fees in Poland.

The research is part of Statutory Research conducted within the Real Estate Economics and Investment Process Department tiled "Institutional Determinants of the Development of the Real Estate Sector". It refers to methodology and issues developed by Małkowska and Uhruska (2018), and Najbar and Węgrzyn (2018) in their previous works.

\section{Literature review}

In view of the general theory of management, the idea of property management can be described as a dynamic process in which the managing subject influences the object being managed. It covers the entire sequence of the four basic functions of management - planning, organizing, directing (people) and controlling. The process consists of constant coordination and integration of the resources related to the real estate (human, material, financial and informational) in order to efficiently achieve the goals and expectations of real estate owners. Thus, property management can be considered as a set of sequences and the mutual relations between each function of management regarding both the current and the long-term activity of the property manager (Muczyński et al., 2015). Apart from the traditional approach to management functions, the service provided by property manager can also be divided into four clusters, namely: administrative, marketing, investment/finance and physical management (Baharum et al., 2016).

In the scope of administrative duties, the property manager is required to regularly monitor outgoings, income, and expenditure regarding a property. Property owners may also expect legal, contractual enforcement of the terms of leases and other agreements. Sometimes the property manager is expected to provide advice on matters regarding sale, purchase and lease. The property management personnel may also be required to formulate and execute necessary marketing programs as well as promotions and other advertising strategies to attain or assist in increasing the occupancy rate or sales. The property manager also acts as a finance or investment advisor, seeing as how the property management team is considered to be the representative of the property owner in realizing an optimum return on his or her investment, acting as the owner's consultant whenever a property investment opportunity arises. That is why it is necessary that proper budgeting and financial records be maintained. The physical function of property management often refers to facility management. In addition to this, the property managers are expected to monitor the quality and functionality of the property structures, assets, and common areas. They are also required to advise the property owner on the necessity of upgrading the property or for the merging of interests, whenever needed. To sum up, the subject of the property management service seems to be characterized by a high level of complexity.

Moreover, the following areas of property manager activity can be distinguished (Najbar, 2013):

- activities related to the implementation of specific management functions (in the scope of administrative, marketing and finance/investment and physical management),

- operational/maintenance services related directly to real estate services, among which we can distinguish:

- obligatory services (e.g., media supply, technical service and maintenance, financial service),

○ facultative services (e.g., design, legal service, insurance). 
Relations between the managing entity and the owner are set up via generally applicable regulations and the contractual arrangement. In general, the management entity acts on the benefit of the owner to the extent specified in the property management contract (Najbar \& Nalepka, 2010). The property manager does not have the right to go beyond the scope of this contract unless this results directly from the law. The obligations of the parties described in the contract are reflected in the scheme of remuneration of the property manager. Therefore, it is in the interest of both parties to precisely define the issue of payment in the management contract (Tertelis 2003). Usually, both parties specify the amount of remuneration or the method of its calculation in the contract. In addition, they should specify, in detail, the obligations for which the property manager receives regular payments and the activities for which he or she is entitled to additional remuneration (Gondring, 2009; Kelley, 1981). Therefore, in principle, we can distinguish two types of remuneration of a property manager:

1. basic - related to the standard functions performed by the property manager and described in a contract,

2. additional (supplementary)- related to above-standard operations - this remuneration can also be specified in a contract but it happens that the need to provide a specific service occurs when the property manager is already operating on the facility, e.g., acting as a project manager during the renovation process.

In the wake of the above, it is necessary to indicate the methods of calculating the remuneration of the property manager. The most common methods of determining the amount of remuneration include:

1. lump sum - a predetermined amount of remuneration for a given property (building or premises) given as the amount of product of the management rate and a specified area of the property,

2. commission - variable remuneration determined as a specified percentage of potential or effective revenues from real estate, its value or enforced receivables.

Both basic and additional remuneration may be determined on the basis of a specific benchmark. It is worth noting that both calculation methods apply to the remuneration of the manager for basic and above-standard activities.

Returning to the standard activities, they will differ in particular types of real estate and will depend on the nature of the property and the goals set by its owner. For residential real estates in Poland, the calculation of basic remuneration is usually based on the total usable space. In Germany, the remuneration of property managers in residential housing buildings is calculated per apartment (Verwalter - Verguetungen in Deutschland 2010). In the case of commercial real estate, the basis could be the market value of the property or cash flows from renting or planned rental income. In practice, it is also often calculated on the basis of effective rental income.

The conducted research in Poland indicates that basic remuneration is most common and takes the form of a lump sum being the product of the negotiated management rate and the usable area of the property (Nabar \& Węgrzyn, 2018). These fees are usually fixed and do not include mechanisms allowing their change over time. However, it is worth noting that the amount of remuneration may be additionally valorised according to various variables defined by the parties in the management contract (including the inflation rate).

Apart from basic remuneration (paid for standard activities), the property manager may obtain payments from other services. This can be calculated, e.g. as a percentage of the total sum of rent collected.

A mixed remuneration combines both of the described forms. These types of remuneration are more likely to be applied in the case of commercial property management where the manager is also obliged to conduct activities to attract tenants through a well thought-out and carefully planned marketing campaign (Tertelis, 2003). These methods are well-established in the area of office space management. In this case, a commonly used method is to determine the percentage of the rental income obtained by the owner or to establish a fixed rate for the space rented.

In order to conduct a profitable business, the manager should also consciously calculate all the costs related to the management of a given real estate. The need for insightful cost analysis and search for cost savings results mainly from a growing competition on a service property management market (Lam, 2012; Carswell, 2017). The important thing is to identify fixed and variable costs of managing a property (Muhlebach \& Alexander, 2007). Fixed costs include payroll costs for the executive property 
manager and administrative staff, comptroller, rent for the office space, equipment costs, insurance, general and administrative costs, etc. They do not always depend on the size of the management portfolio and can be expanded for detailed cost accounting. Variable costs are those directly related to the managed property and usually result from additional services, e.g. technical inspections or carrying out renovations. The property manager should take into consideration both types of costs to estimate the property management fee.

One of the specific features of the real estate market is also its local character (Foryś et al., 2014). This feature significantly affects investors' decisions on the real estate market. According to P. Eichholtz et al. (1995), the conventional approach to defining diversification categories is to use a property type and geographical region for real estate portfolios. Investors often face a dilemma of whether it is more efficient to diversify across regions within a single property type or across property types within a region. For the property manager's sake, we may assume that the more common strategy is to seek diversification by property type within the region. Thus, is seems that the diversified level of regional economic development may affect the property management fees.

Tertelis et al. (2009) also refer to the development of property management companies and the diversification of their portfolios, pointing out that it is a great challenge for these entities to take over another type of space for management. Diversifying the range of property types is also followed by the need to redefine the scope and quality of service. Additionally, with regard to the stability of the management company's revenues, it is more beneficial to manage a larger (more significant) number of smaller properties than a few large objects, because the loss of one of the later from the portfolio may result in a substantial drop in the company's revenues.

To sum up, the conducted literature study allowed us to distinguish the following set of factors that exert an impact on the property management rates (see: Tertelis et al. (2009); Uhruska and Najbar (2006)):

1. Connected directly to the property:

a. the property owner's goals and objectives,

b. status of the owner,

c. phases in the real estate life cycle,

d. the level of services provided by the property to its users, (the range of facilities available to its users)

e. the technical potential of the property

f. the current form of the use of the property

g. the expected cost of managing the property.

2. Connected directly to the manager:

a. the level and scope of services provided by the property management firm,

b. experience of the property manager,

c. the legal form of running a business,

d. profit assumed by the management company,

e. the management company's cost of doing business (staff costs for a given property, the time required to deal with office matters, time and frequency of commuting, inspections, meetings, office and field costs).

3. Shaped by the environment:

a. changing customer requirements,

b. competition from other property managers,

c. legal conditions governing the process of providing services,

d. the location of the property and market size,

e. historical conditions.

In the given set we can distinguish two groups of factors, namely factors having a similar impact on all property management markets and factors exerting an impact on the differentiation in the functioning of individual property management markets. In the article, we will focus on the factors directly related to the property manager and those factors shaped by the environment. We are particularly interested in identifying factors that could potentially affect the differences in property management rates. 


\section{Data and methods}

All the aforementioned factors are considered to exert an impact on the rate of property management fees. However, as some are more important than others, it is reasonable to verify this assumption through empirical research. Thus, the study aimed to answer the following research question: What kind of factors determine property management fees in Poland?

To answer the research question, we have chosen the following research approach. The empirical part of the research was divided into three stages: data collection, data elaboration, and statistical testing. At the first stage, the questionnaire survey was adapted to collect data from property managers in Poland. The purpose of the procedure was to obtain a maximally large test sample. As data on the entire population of property managers in Poland were not available, a purposive sample was chosen. In light of the above, the research was carried out with the help of as extensive participation of professional organizations gathering property managers as possible. Then, selected entities forwarded questionnaires in electronic form to their members.

Table 1

List of professional organizations participating in the survey

\begin{tabular}{|l|l|}
\hline Name of organization & Headquarters \\
\hline Polska Federacja Zawodów Nieruchomościowych & Warszawa \\
\hline Polskie Stowarzyszenie Zarządców Nieruchomości & Warszawa \\
\hline Krajowa Izba Gospodarki Nieruchomościami & Katowice \\
\hline
\end{tabular}

Source: own elaboration.

The questionnaire survey was administered between July 2018 and October 2018. A total of 348 questionnaires were obtained. However, the way of collecting the responses limited the availability of reliable data to calculate the return ratio. Therefore, it was not possible to accurately estimate the relation of the research sample to the total population of property managers in Poland.

Then the data obtained from the respondents were analyzed to select the indicators relevant to the aim of the research. As for the dependent variable, the questionnaire form covered both questions, concerning minimum and maximum fees obtained from property management per square meter. This allows us to decompose the research question on two sub-questions, and to investigate the possible factors of variation separately for minimum and maximum fees.

Considering independent variables, it needs to be stressed that, in the questionnaire, we focused on the form and range of services instead of asking property managers to describe each property separately. That is why the possibility of including factors related to real estate in the research was limited. The list of factors was therefore developed predominately based on the characteristics of property managers. Preliminary analysis of the data allowed a list of nine factors that were incorporated for further statistical testing to be compiled.

We wanted to check which of the given factors exert an impact on the property managers' remuneration, and attempted to solve this problem in the third stage of the research with the help of statistical testing. For each of the described indicators, the zero hypotheses and the alternative hypothesis were considered (see: Faraway 2002):

$$
\begin{gathered}
H_{o}: \mu_{1}=\mu_{2}=\ldots=\mu_{r} \\
H_{1}: \text { not all } \mu_{i}(i=1, \ldots r) \text { are equal }
\end{gathered}
$$

We utilized the analysis of variance (ANOVA) to verify the differences among group means in a research sample (Fink, 1995). We estimated ANOVA for both minimum and maximum fees declared by property managers.

\section{Empirical results}

In the questionnaire, we inquired respondents to give information on the ways of obtaining basic remuneration used (related to the standard functions performed by the property manager and described in a contract) as well as minimum and maximum fees. Respondents could choose one or more ways from the given set of remunerations:

- fixed fees in PLN/m2,

- fees with the valorization, 
- fees related to the results,

- others.

The majority of respondents $(n=244,70 \%)$ indicated that they obtained fixed fees. However, 54 respondents in this group declared that they also obtained remuneration in other forms; in most cases, their fees were valorized $(n=34)$. Groups in which respondents declared only one of the remaining forms of receiving remuneration were by far smaller and amounted to 23 in the case of fees with the valorization, 12 - fees connected to the results, and 29 to others.

Minimum fees oscillated around the average value of PLN55.2 per square meter. Maximum fees reached the average value at PLN95.8 per square meter. The table below illustrates the rates of minimum and maximum fees with a division made according to the factors incorporated in the analysis.

Table 2

The set of factors incorporated in the analysis

\begin{tabular}{|c|c|c|c|c|c|c|c|}
\hline & & \multirow{2}{*}{\multicolumn{3}{|c|}{ Minimum Fees [PLN] dots }} & \multirow{2}{*}{\multicolumn{3}{|c|}{ Maximum Fees }} \\
\hline & & & & & & & \\
\hline & & No & mean & sd & No & mean & $\mathrm{sd}$ \\
\hline \multirow{3}{*}{$\begin{array}{l}\text { The origin of } \\
\text { capital }\end{array}$} & national & 166 & 55.11 & 18.26 & 161 & 96.89 & 45.64 \\
\hline & international & 2 & 50.50 & 7.78 & 2 & 59.50 & 0.71 \\
\hline & mixed & 0 & 0 & - & 0 & 0 & - \\
\hline \multirow{5}{*}{ Legal form } & sole proprietorship & 70 & 54.87 & 14.34 & 69 & 90.16 & 41.43 \\
\hline & $\begin{array}{l}\text { civil/registered } \\
\text { partnership }\end{array}$ & 43 & 51.65 & 12.69 & 45 & 99.00 & 42.97 \\
\hline & Ltd./plc & 25 & 51.36 & 14.89 & 24 & 95.63 & 45.47 \\
\hline & $\begin{array}{l}\text { public } \\
\text { administration }\end{array}$ & 15 & 67.80 & 37.47 & 13 & 117.69 & 68.30 \\
\hline & cooperative & 6 & 65.00 & 13.05 & 6 & 74.67 & 10.23 \\
\hline \multirow{5}{*}{ Voivodeship } & Śląskie & 37 & 56.51 & 13.05 & 33 & 108.55 & 67.65 \\
\hline & Mazowieckie & 30 & 56.97 & 18.18 & 31 & 94.94 & 31.51 \\
\hline & Małopolskie & 21 & 56.10 & 17.84 & 23 & 99.48 & 33.53 \\
\hline & Pomorskie & 13 & 66.54 & 34.22 & 12 & 107.25 & 61.38 \\
\hline & others & 65 & 50.90 & - & 64 & 82.45 & - \\
\hline \multirow{4}{*}{$\begin{array}{l}\text { Size of the city } \\
\text { in thousands }\end{array}$} & over 500 & 62 & 57.73 & 21.33 & 64 & 100.81 & 39.60 \\
\hline & $100-500$ & 49 & 56.37 & 15.36 & 45 & 107.42 & 61.80 \\
\hline & $50-100$ & 9 & 51.78 & 20.83 & 9 & 91.67 & 30.10 \\
\hline & up to 50 & 29 & 51.41 & 13.44 & 29 & 74.07 & 22.93 \\
\hline \multirow{2}{*}{$\begin{array}{l}\text { Portfolio } \\
\text { structure }\end{array}$} & $\begin{array}{l}\text { residential } \\
\text { property } \\
\text { domination }\end{array}$ & 133 & 55.14 & 17.81 & 130 & 95.48 & 46.98 \\
\hline & $\begin{array}{l}\text { commercial } \\
\text { property } \\
\text { domination } \\
\end{array}$ & 7 & 55.00 & 23.98 & 6 & 97.33 & 32.66 \\
\hline \multirow{3}{*}{ Experience } & up to 3 years & 4 & 58.75 & 27.20 & 3 & 96.67 & 25.17 \\
\hline & $3-10$ years & 30 & 54.50 & 12.51 & 31 & 95.35 & 47.93 \\
\hline & more than 10 years & 130 & 54.95 & 18.91 & 125 & 96.22 & 45.09 \\
\hline \multirow{2}{*}{$\begin{array}{l}\text { Lease } \\
\text { management } \\
\text { in the offer }\end{array}$} & yes & 138 & 54.17 & 18.62 & 134 & 92.82 & 40.19 \\
\hline & no & 30 & 59.10 & 15.61 & 29 & 113.14 & 63.04 \\
\hline \multirow{2}{*}{$\begin{array}{l}\text { Development } \\
\text { in a 3-year } \\
\text { period }\end{array}$} & yes & 67 & 59.09 & 21.50 & 63 & 98.60 & 40.93 \\
\hline & no & 84 & 52.07 & 15.63 & 81 & 91.21 & 44.76 \\
\hline Incomes in a 3- & increased & 16 & 54.13 & 12.82 & 16 & 115.25 & 62.39 \\
\hline
\end{tabular}




\begin{tabular}{llcccccc}
\hline year period & remained stable & 63 & 59.21 & 19.43 & 55 & 93.45 & 33.88 \\
\cline { 2 - 7 } & decreased & 105 & 52.56 & 16.98 & 107 & 98.36 & 50.60 \\
\hline
\end{tabular}

Source: own elaboration.

It can be seen from the table above that, apart from two cases, property managers work in national companies. The prevailing number of respondents operates in the area of four voivodeships, i.e.: Śląskie, Mazowieckie, Małopolskie, and Pomorskie. The most popular legal form of operation is an individual business (sole proprietorship). The second important form of legal organization is a civil or registered partnership. Detailed information on the regional distribution of respondents and the legal form of delivering services is presented in Figure 1.

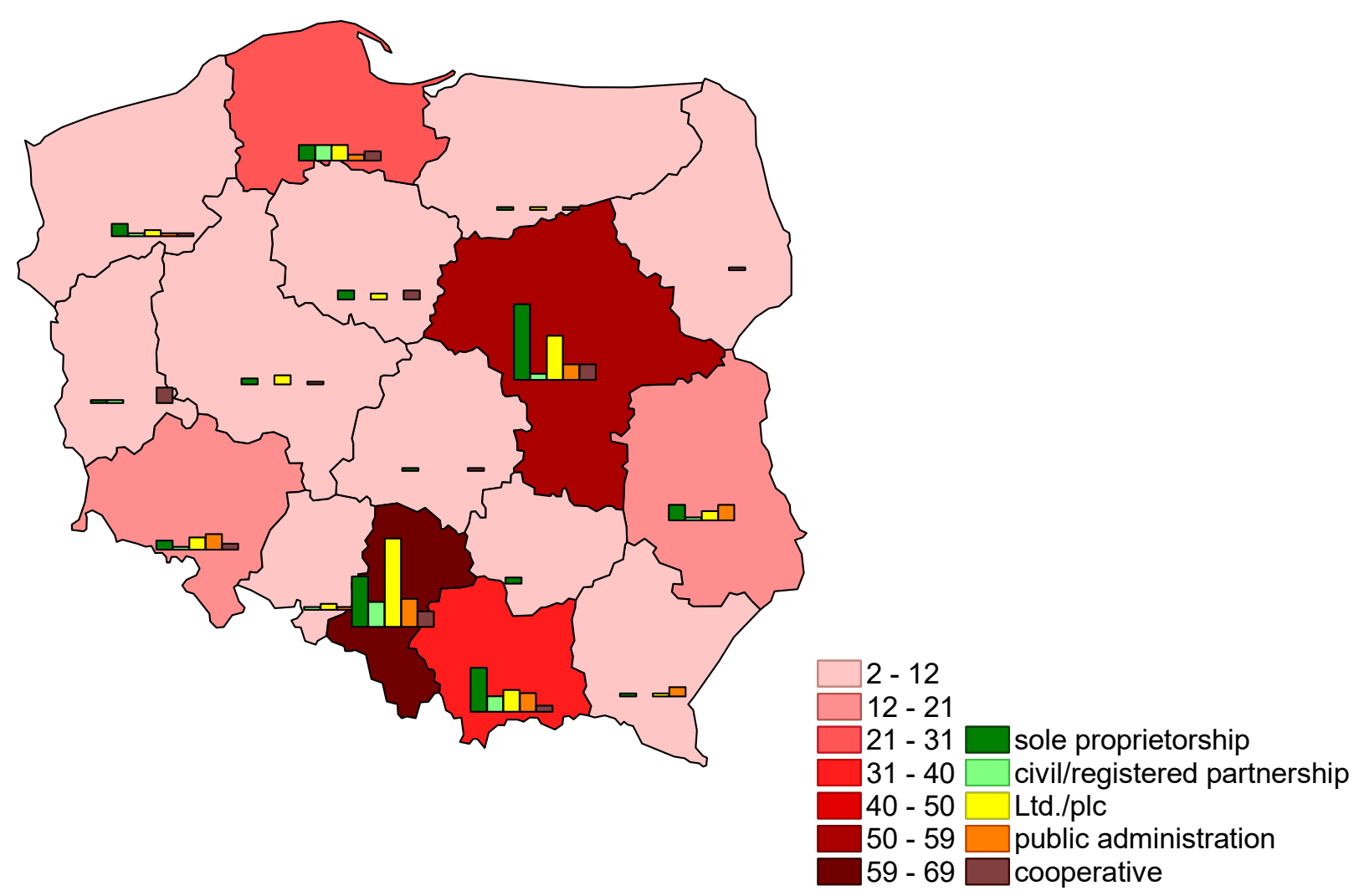

Fig. 1. Number of responses according to region and type of legal form. Source: own elaboration.

Considering the size of the market in which property managers provide their service we can notice that almost one-half of respondents manage real estates located in large urban centers. From the data, we can see that those property managers who operate on larger markets have a bigger chance of obtaining higher remuneration for their services. The main area of business still applies to residential properties. No more than $5 \%$ of respondents declared that commercial real estate dominates in their portfolio structure. However, the comparison between means in both groups suggests that there are no substantial differences in the rates of fees for property management.

Following the preliminary analysis of basic statistic, we proceeded to the analysis of variances. In order to verify the hypotheses, a one-way analysis of variance was carried out. As a result, the analysis of variances revealed that only in one case, namely the size of the city, can significant differences in maximum fees be noticed. However, based on the Shapiro-Wilk test results, the hypothesis of normality of the dependent variable was rejected. That is why the analysis of variances was conducted based on Kruskala-Wallisa test. As a result test Kruskala-Wallisa: H ( 3, N= 147) $=13,76406 \mathrm{p}=0.0032$ proved that there are statistical differences between compared groups. The results are plotted on the chart below: 


\section{S sciendo}

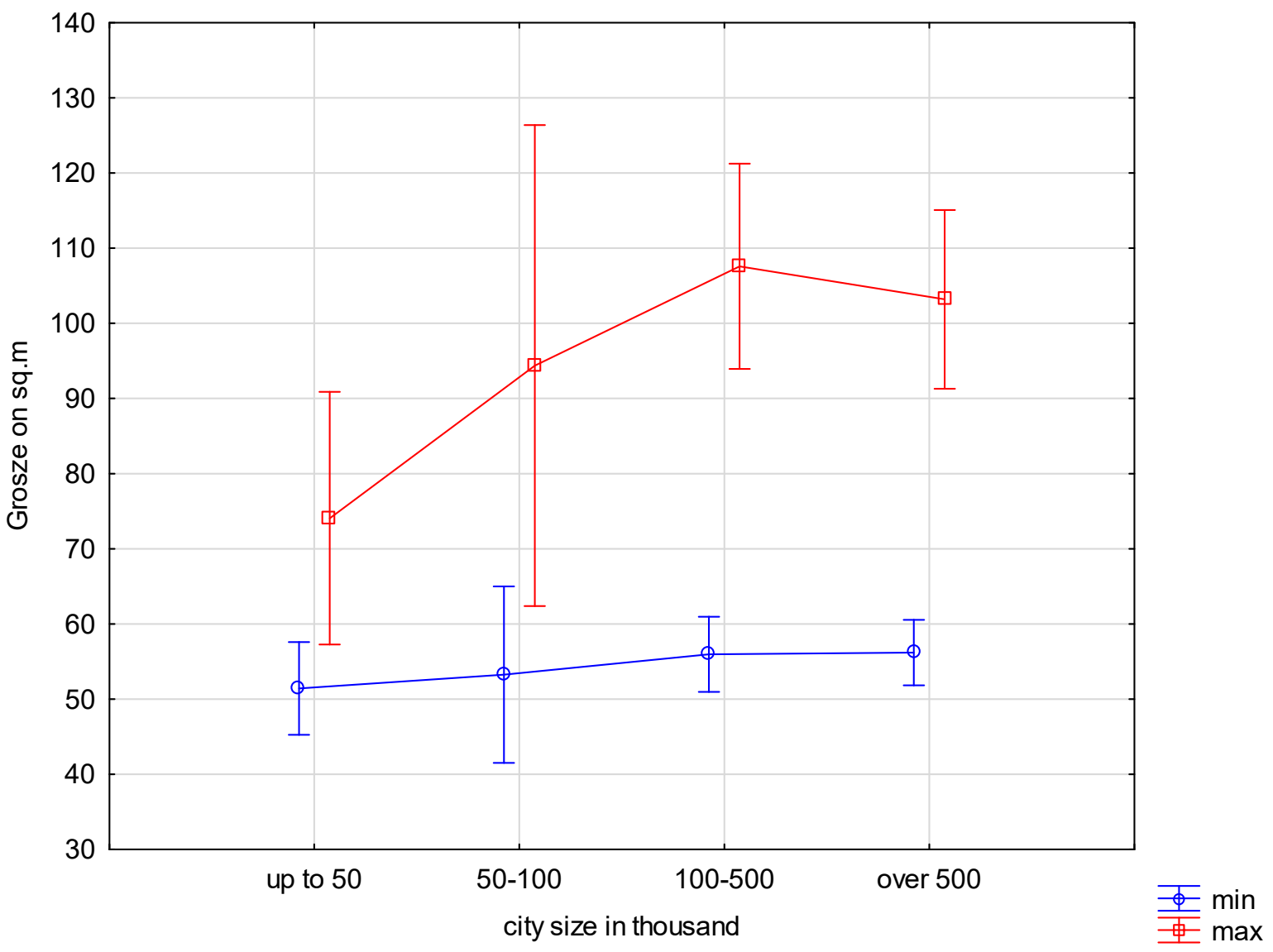

Fig. 2. Minimum and maximum fees in cities. Source: own elaboration.

Then, in order to investigate which groups differ significantly, the post hoc test was conducted. The results of the test are shown in the table below:

Post hoc test for maximum fees according to the size of the city (in thousands)

\begin{tabular}{ccccc}
\hline & Up to $\mathbf{5 0}$ & $\mathbf{5 0 - 1 0 0}$ & $\mathbf{1 0 0 - 5 0 0 ~ t h s ~}$ & Over 500 ths \\
\hline & R: 48.655 & R:73.833 & R:76.878 & R:83.484 \\
\hline Up to 50 & & 0.7273 & 0.0323 & 0.0015 \\
\hline $\mathbf{5 0 - 1 0 0 ~ t h s ~}$ & 0.7273 & & 1 & 1 \\
\hline $\mathbf{1 0 0 - 5 0 0 ~ t h s ~}$ & 0.0323 & 1 & & 1 \\
\hline Over 500 ths & 0.0015 & 1 & 1 & \\
\hline
\end{tabular}

Source: own elaboration.

The obtained results indicate that the fees in the smallest cities are statistically different from fees in cities between 100-500 thousand and cities over 500 thousand. We also investigated the structure of property managers in each group of cities according to the legal form of business (Table 4).

As we can see from the data in the table above, the group of smallest cities is represented by $24 \%$ property managers. Such managers who declared that they work for public administration dominate in these groups. Interestingly, this group of property managers is mostly represented in the smallest urban regions. This could be attributed to the specific character of professional organizations who intermediated in the survey. The following group of cities, namely these ranging from 50 to 100 thousand citizens, gathered only $7 \%$ of respondents. Cooperatives dominate in this group. Additionally, this group is characterized by the highest rate of differentiation in maximum fees. However, due to the small size of the sample, the ability to draw unambiguous conclusions is limited. 
Table 4

Structure of property managers according to the legal form and size of the city (no. of valid responses 259)

\begin{tabular}{lccccc}
\hline \multirow{2}{*}{ Legal form } & \multicolumn{5}{c}{ Size of the city in a thousands } \\
\cline { 2 - 5 } & up to 50 & $50-100$ & $100-500$ & over 500 & Together \\
\hline $\begin{array}{l}\text { sole } \\
\text { proprietorship }\end{array}$ & $6 \%$ & $1 \%$ & $9 \%$ & $17 \%$ & $\mathbf{3 3} \%$ \\
\hline $\begin{array}{l}\text { civil/registered } \\
\text { partnership }\end{array}$ & $1 \%$ & $0 \%$ & $4 \%$ & $5 \%$ & $\mathbf{1 0} \%$ \\
\hline Ltd./plc & $3 \%$ & $2 \%$ & $12 \%$ & $10 \%$ & $\mathbf{2 8} \%$ \\
\hline $\begin{array}{l}\text { public } \\
\text { administration }\end{array}$ & $11 \%$ & $1 \%$ & $1 \%$ & $3 \%$ & $\mathbf{1 5 \%}$ \\
\hline cooperative & $3 \%$ & $3 \%$ & $4 \%$ & $2 \%$ & $\mathbf{1 2} \%$ \\
\hline others & $0 \%$ & $0 \%$ & $1 \%$ & $\mathbf{3 8} \%$ & $\mathbf{1 0 0} \%$ \\
\hline Together & $\mathbf{2 4 \%}$ & $\mathbf{7 \%}$ & $\mathbf{3 1} \%$ & & $\mathbf{3}$ \\
\hline
\end{tabular}

Source: own elaboration.

In the following two groups of cities, the rates of minimum and maximum fees are the highest. The most noticeable difference is related to the share of property managers running their own business. They mostly choose the largest city centers to start their business. The reason for this is the availability of new commercial and residential properties that could be included in the company portfolio.

\section{Discussion and conclusions}

The applied methods of the analysis of variances allowed us to assess what factors exert an impact on project management fee differentiation in Poland. Surprisingly, we did not detect statistical relations that could confirm that a legal form of providing services or property type in the portfolio have an influence on the diversification of both minimum and maximum fees for property management. In fact, the data did not prove that property management fees are diversified depending on the voivodeships where the business is run.

What we did find out is that, according to the conducted analysis, the maximum fees depend mostly on the size of the city. These results are in line with the conjecture that the largest urban centers are perceived as more desirable for conducting property management services.

A limitation of the study is the fact that the respondents that took part in the survey represented mainly only a few voivodeships, namely Śląskie, Mazowieckie, Małopolskie, and Pomorskie. However, these are regions that, together, create almost half of the GDP in Poland (in 2016, the estimated GDP reached $48.3 \%$ of the total GDP). Nevertheless, the ability to draw conclusions for all property managers in Poland may be limited. In spite of these limitations, the results obtained offer an interesting insight into the organization and practices of firms providing property management services. The results indicate that, besides the cost and the range of services described in a property management contract, other aspects also exert an impact on determining the range of fees.

Concerning the above, it is worth stressing that the scope and complexity of the property management market has evolved over many years. This has resulted in the need for professional management and a need to focus professional skills on services provided to distinct submarkets (Goss, Campbell, 2008). That is why it is worth subjecting the market of property management services to more detailed analyses. Further research could focus on investigating segmentation on the property management market.

\section{References}

Baharum, Z. A., Hwa, T. K., \& Salleh, S. M. (2016). Competency Framework for the Property Management Industry. Environment-Behaviour Proceedings Journal, 1(4), 3-12. https://doi.org/10.21834/e-bpj.v1i4.114.

Carswell, A. (2017). An analysis of operating expense control within U.S. multifamily properties. Property Management, 35(1), 48-66. https:/ / doi.org/10.1108/PM-10-2015-0053.

Gondring, H. (2009). Immobilienwirtschaft, Handbuch fuer Studium und Praxis (2nd ed.). Vahlen. 
Eichholtz, P. M., Hoesli, M., MacGregor, B. D., \& Nanthakumaran, N. (1995). Real estate portfolio diversification by property type and region. Journal of Property Finance, 6(3), 39-59. https:/ / doi.org/10.1108/09588689510101676.

Faraway J. J. (2002). Practical regression and ANOVA using $R$.

Fink, A. (1995). How to analyze survey data (Vol. 8). Sage.

Foryś, I., Foryś, I., Gromadowska, D., Gutowski, J., Krajewski, P., Malinowski, W., \& Mazurek, Z. (2014). Zarządzanie nieruchomościami handlowymi (Commercial property management). Wydawnictwo Poltext.

Goss R. C., Campbell H. L. (2008). The Evolution of Residential Property Management: From Caretaker to Income Maximization Managers. Housing and Society, 35(1), 5-20.

Kelley, E. N. (1981). Practical Apartment Management, Sec. edition, Institute of Real Estate Management, Chicago.

Lam, Y. M. (2012). Economic perspective on outsourcing of property management services. Property Management, 30(4), 318-332.

Małkowska, A., \& Uhruska, M. (2018). Uwarunkowania instytucjonalne działalności zawodowej rzeczoznawcy majątkowego - stan obecny i pożądane kierunki zmian. (Institutional determinants of the professional activity of a property valuation - current status and desirable directions of changes). World of Real Estate Journal, 3(105), 8-12.

Muhlebach, R. F., \& Alexander, A. A. (2007). Insider's Tips to Operating a Successful Property Management Company, IREM (Institute of Real Estate Management), Chicago.

Muczyński, A. (2015). An Integrated Approach to Real Estate (Portfolio) Management. Real Estate Management and Valuation, 23(2), 5-16. https:/ / doi.org/10.1515/remav-2015-0011.

Muczyński, A., Źróbek, R., Foryś, I., Kempa, O., Bieda, A., Pęska, A., . . Biłozor, A. 2015, Real estate Management. In Spatial Analysis supported by GIS tools, Croatian Information Technology Society, GIS Forum, Zagreb, Croatia.

Najbar, K. (2013). Rynek usług zarządzania nieruchomościami (Property Management Services Market). Poltext.

Najbar K., \& Nalepka, A. (2010). Firmy zarządzające nieruchomościami w Polsce (Property management companies in Poland). Świat Nieruchomości, 1(71), 16-21.

Najbar K., \& Uhruska, M. (2006). Property management strategies (Strategie zarządzania nieruchomościami). Studia i Materiaty TNN, Journal of the Polish Real Estate Scientific Society, 14(1), 149-161.

Najbar, K., \& Węgrzyn, J. (2018). Characteristics of real estate management services in Poland. World of Real Estate Journal, 4(106), 5-10.

Nätti, S., Pekkarinen, S., Hartikka, A., \& Holappa, T. (2014). The intermediator role in value cocreation within a triadic business service relationship. Industrial Marketing Management, 43(6), 977984. https:/ / doi.org/10.1016/j.indmarman.2014.05.010 .

Preliminary estimates of gross domestic product by voivodships in 2016, GUS, www.stat.gov.pl (15.03.2019)

Read, D. C., \& Carswell, A. (2018). Is property management viewed as a value-added service? Property Management.

Tertelis, M. (2001). Jak wybrać profesjonalnego zarządcę nieruchomości wspólnej. (How to choose a professional property manager). Nieruchomości. C.H. Beck, December 2001, 9-12.

Tertelis, M. (2003). Umowa o zarządzanie nieruchomościa (Property management contract). C.H. Beck.

Tertelis, M., Karp, J., \& Vieyra, S. (2009). Zarządzanie wartością nieruchomości mieszkaniowych (Residential property value management). C.H. Beck.

Vargo, S. L., \& Lusch, R. F. (2008). Service-dominant logic: Continuing the evolution. Journal of the Academy of Marketing Science, 36(1), 1-10. https://doi.org/10.1007/s11747-007-0069-6.

Verwalter - Verguetungen in Deutschland. (2010). Studie. Bundesvereinigung Spitzenverbaende der Immobilienwirtschaft.

Żelazowski, K. (2011). Regionalne zróżnicowanie cen i ich determinant na rynku mieszkaniowym w Polsce. (Regional differences in prices and their determinants on Polish housing market). Studia $i$ Materiały Towarzystwa Naukowego Nieruchomości, 19(3), 98-106. 